\title{
SANITARY AND HYGIENIC EDUCATION OF CHILDREN AND ADULTS UNDER THE CONDITIONS OF THE COVID-19 PANDEMIC IN MEASUREMENT OF THE ACHIEVEMENTS OF PUBLIC MEDICINE OF GALICIA (END OF THE XIX - 30S OF THE XX CENTURY)
}

DOI: 10.36740/WLek202109135

\author{
Halyna V. Bilavych', Jan V. Bilawicz², Larysa V. Slyvka' , Mariia V. Klepar', Mykola P. Pantiuk, Nadiya O. Fedchyshyn, \\ Borys P. Savchuk ${ }^{1}$ \\ 'VASYL STEFANYK PRECARPATHIAN NATIONAL UNIVERSITY, IVANO-FRANKIVSK, UKRAINE \\ ${ }^{2}$ WARSAW MEDICAL UNIVERSITY, WARSAW, POLAND \\ ${ }^{3}$ DROHOBYCH IVAN FRANKO STATE PEDAGOGICAL UNIVERSITY, DROHOBYCH, UKRAINE \\ ${ }^{4}$ TERNOPIL NATIONAL MEDICAL UNIVERSITY, TERNOPIL, UKRAINE
}

\begin{abstract}
The aim: To analyze the leading trends in sanitary and hygienic education of children and adults in Galicia during the late XIX - the 30s of the XX century and define opportunities to use this historical experience in the current context of the spread of COVID-19 virus in Ukraine.

Materials and methods: Chronological, historical, specific search, content-analysis- provide selection and analysis of the source base, allow to determine general trends, directions of development, achievements and gaps of sanitary and hygienic education of children and adults in Galicia in the late XIX - 30sof the XX century; extrapolation and actualization - focus on creative thinking, adaptation and use of this historical experience in today's conditions.

Conclusions: Under the current conditions of the COVID-19 spread, analysis of this retro experience projects to develop a scientific concept of health education, which would outline theoretical approaches to studying this problem, creating a comprehensive state program aimed at preventing infectious diseases, restoration of gene elaboration of clear recommendations on observance of sanitary and hygienic norms and conditions established by quarantine zones, carrying out anti-epidemic measures at educational institutions and among the adult population, informing about prevention and peculiarities of the COVID-19 disease spread, etc.
\end{abstract}

KEY WORDS: Ukrainian Hygienic Society, sanitary and hygienic education, hygiene, health preservation

Wiad Lek. 2021;74(9 p.l):2222-2227

\section{INTRODUCTION}

Given the spread of the COVID-19 virus in the world, its modification, the emergence of new waves of the disease, often ineffective actions of the governments, increasing mortality among humans, etc. the activation of the public factor that would help the state, medical workers to stop the pandemic, reduce its consequences and, most importantly, to prevent new infections, is needed. This can be done through massive public health education.

During the late XIX- the 30s of the XX century, the Austro-Hungarian Empire, the Second Commonwealth and Galicia, which was part of them, had a similar experience with the spread of infectious diseases. Through the efforts of activists who belonged to numerous Ukrainian medical (Ukrainian Hygienic Society, Ukrainian Medical Society, "Medychna Hromada" (Medical Community)), cultural, educational, children's and youth, charitable, and other public organizations (Union of Ukrainian Women, "Silskyi Hospodar" (Farmer), "Ridna Shkola" (Native School))","Prosvita", "Akademichna Hromada" (Academic
Community), Petro Mohyla Society, etc.) effective forms, original mechanisms, means of mass sanitary and hygienic education of children and adults, which really affected the health of people, were created. Similar events were held by Polish public associations. And, for example, in the field of tuberculosis control, Polish and Ukrainian societies sometimes acted as a joint front.

Today it is important to form knowledge, beliefs about the need to comply with sanitary and hygienic standards during a pandemic among citizens, especially children, youth, adults. This requires the establishment of a system of mass medical education and the promotion of hygienic and health-preserving knowledge [1].

Despite the fact that scientists (K. Brożek, J. Hanitkevych, A. Łupienko, V. Trach and other authors) are actively studying the activities of Ukrainian medical societies in Galicia and some personalities representing the medical movement in the late XIX- the 30s of the XX century, the scientific problem raised in the title of the article has not been deeply studied [2-5]. 


\section{THE AIM}

To analyze the leading trends of sanitary and hygienic education of children and adults in Galicia during the late XIX - the 30s of the XX century and to determine the possibilities of using this historical experience in the current conditions of COVID-19 virus spread in Ukraine.

\section{MATERIALS AND METHODS}

The study uses a number of scientific methods: chronological, historical, specific search, content analysis - provide selection, analysis of the source base, allow to identify general trends, directions of development, achievements and gaps of sanitary education of children and adults in Galicia in the late XIX -30s of the XX century; extrapolation and actualization - focus on creative thinking, adaptation and use of this historical experience under the current conditions.

\section{REVIEW AND DISCUSSION}

In Galicia, which was part of Austria-Hungary, at the end of the XIX century a system of massive public medical education was formed, covering all areas of public medical care (sanitary and hygienic segment (sanitary and health rehabilitation, sanitary and hygienic education), sobriety movement, health preservation and physical education, etc.), which was constantly evolving and improving[6].

An important role in this process of public health education was played by the "propaganda and information" (publishing) section, which directed the work in the context of dissemination of knowledge and promotion of materials on health care. Among the main means, methods and forms of activity we distinguish the following: "readings" (essays, speeches with reports); counseling people; printed word (publications in periodicals in the form of articles or notes, separate headings); publication of information leaflets ("flyers", postcards, calendars, etc.) and popular science literature in the form of thematic books; organization of "traveling" (mobile) hygienic exhibitions; arrangement of hygienic courses; creation of thematic literary works; illustration of "hygienic topics" of books; holidays, etc. These means of education were usually used comprehensively: doctors, medical students, educators or public figures, going to "lectures" in the villages and towns of Galicia, took with them the relevant literature, acquainted with periodicals, organized traveling exhibitions and more. All these forms had a practical purpose: they provided children and adults with the necessary practical recommendations for health care; most of them took place in the villages mostly on Sundays or holidays in the reading rooms of "Prosvita" or other Ukrainian societies.

The Ukrainian Hygienic Society (UHS) (1929-1939), one of the youngest participants in the movement for a healthy lifestyle, brought together Ukrainian physicians (generally Ukrainian students) who, among other things, worked with great dedication in the field of health care and medical support of local Ukrainians, promoted the basics of hy- gienic knowledge among the rural population, joined along with other Ukrainian public associations in educational activities, selflessly and free of charge worked in "Narodna Lichnytsia", etc. Similar Polish and Jewish societies operated in the region, but Ukrainians, especially children, were deprived of their attention as well as of state care. According to the statute, the UHS performed the following public tasks in the field of health care: spread hygienic knowledge among the population; created a network of treatment and prevention facilities, which provided free medical care and counseling to people; engaged in the training of mid-level specialists to serve the inhabitants of towns and villages; involved large sections of the population in solving public health problems [7: 196-197]; published popular brochures, the monthly "Narodne Zdorovlia" (Public Health) (since 1937). In addition, it organized and maintained outpatient clinics, tuberculosis dispensaries, "sports" and "eugenic counseling" (genetic laboratory - authors) (Lviv), etc., as well as created vacation centers for children and youth, among them the most famous climatic stationnear Pidlyute (Rozhnyativ district, Ivano-Frankivsk region)).

The UHS established contacts with similar medical sections of student societies in Krakow, Poznan, Vilnius, the Polish Hygienic Society and the Tuberculosis Control Society; Jewish Health Society in Lviv, specialized publishers of medical periodicals ("Medical Archive", "Bulletin of the Ukrainian Red Cross" "Way to Health" from the USSR, "Questions of Tuberculosis" from the USSR, "Zdrowie" and "Gruzlica" from Warsaw-Poland). In September 1929, the UHS took part in the Educational Congress in Lviv, where M. Panchyshyn delivered a report "Healthy Village House" [7: 198-199].

Its success, for example, is illustrated by the results of the two year activity: as of 1931, there were 182 members of the UHS, a third of whom were medical students; the branches have been established in the region; 150 essays were read, which were listened to by more than 17000 people; a "sports and medical council" was established, it conducted a medical examination of Ukrainian athletes, gave them advice and recommendations on effective training, improvement of physical development, healthy lifestyle; an "eugenic council", which provided advice on avoiding hereditary diseases to persons who wanted to get married (according to Ya. Hanitkevych, this was "the first medical and genetic consultation ... which was to improve the gene pool of the nation" [3]), was founded.

The UHS had great prospects for the health improvement of the Galicia population. Its first important event was a screening of more than three dozen villages that suffered the most from infectious diseases. Its results showed that the main reason (in $80-90 \%$ of cases) of the spread of "plagues" was the non-isolation of patients from healthy people. Another example: only during 1929-1930 (almost for the first time in the region) with the help of 35 radiographs purchased by the society almost a third of the rural communities of Galicia were examined [8;9].

Therefore, an important area of activity was explanatory work on disease prevention and formation of basic sanitary 
and hygienic knowledge among children and adults. Based on the reports on the activities of the UHS for 1929-1931, we can see some success in this area: members of the UHS prepared about 80 thematic abstracts, gave more than 300 lectures, held dozens of three-day sessions. The number of participants in these educational activities is impressive: about 40,000-50,000 people. Ukrainian doctors and students distributed thousands of copies of "essays" (brochures, leaflets) and "tables" (campaign posters), which in an accessible form introduced children and adults to the symptoms of the disease, providing care to patients and measures to prevent emerging and spread of disease. It is worth noting that such preventive and explanatory activities were spread by activists in Volyn, Kholmshchyna, and Polissya regions. Slightly smaller volumes of work were in the anti-alcohol and venereology section of the UHS [8;9].

Such UHS activities caused a keen interest in healthcare among the general public. People began to understand the need to participate in the health movement [10:319].It was especially relevant in December - the month of the fight against tuberculosis in many European countries and in Galicia - at the initiative of the International Anti-Tuberculosis Union.

Back in May 1929, thanks to the efforts of M. Panchyshyn and "Narodna Lichnytsia", the UHS established the first Ukrainian anti-tuberculosis dispensary in Lviv. Its purpose was to examine the inhabitants of Galicia for the early detection of tuberculosis patients, and thus their treatment and prevention of this disease. The spread of tuberculosis in the region was threatening to the gene pool of Ukrainians. This was well understood by the activists of the Ukrainian medical movement: for example, $16 \%$ of the students inspected in the western region in 1927 had tuberculosis [6]. Professor M. Panchyshyn initiated scientific research aimed at fight against tuberculosis. The first stage was the collection of information about the state of the disease. Questionnaires were developed, which were filled out by the organizers of "hygienic reports" in the villages. The lecturers talked to the local population, the village government (council), finding out the state of the sanitary-epidemiological situation; only for the first year of the survey, information on 50 settlements from different counties (from Zakarpattia to Polesia) was processed [7:205].

Thus, the survey of the Ukrainian population of Galicia, the study of living conditions of Ukrainians through questionnaires showed that medical science served the development of social medical care, responded to the challenges of time and needs of life, as well as outlined the work of the UHS. In connection with the elimination of "hygienic illiteracy" of the population there was a need to intensify educational and advisory activities of members of the section on fight against tuberculosis. For this purpose the following equipment was purchased: 35 radiographs of various forms of human and animal tuberculosis, 34 models of prevention and epidemiology, 36 volumes of scientific literature; dozens of lectures were arranged (in 1929 , they were attended by about 13,000 listeners [ $8 ; 9]$ ).

The UHS concentrated its activities not only in Galicia, but also spread to other Ukrainian lands: in the early 1930s it cooperated with a number of scientific and public institutions of Soviet Ukraine - the Tuberculosis Clinical Institute, the State Venereological Institute in Kharkiv, the Tuberculosis Institute in Kyiv, All-Ukrainian Society of Cultural Relations, etc. However, apart from a few facts of literature exchange, permanent cooperation could not be established. Cooperation with the Polish Anti-Tuberculosis Union, the Polish Hygienic Society, the Jewish Health Society, and other Polish national organizations was more successful: several joint exhibitions, lectures, and other events were held to demonstrate the success of such forms of cooperation.

The first anti-tuberculosis exhibition, which was visited by about 20,000 Lviv residents and guests, was organized in December 1929 by the UHS together with the Polish Society for the Fight against Tuberculosis in Lviv. Then it was decided to carry their thematic expositions and exhibits through the "terrain" of the region. Not only the Ukrainian peasantry, but also the Polish and Jewish communities were very interested in the anti-tuberculosis exposition created in July 1931 by the UHS and "Prosvita" in Terebovlia (it was visited by about 10,000 adults and children). In 1932 the same thematic exhibition took place in Sokal region, in 1933 - in Kalush, in 1937 - in Khodoriv, and in the beginning of 1938 - in Kopychyntsi [11; 12].

The educational value was given to them by the "reports" of activists who accompanied such events, as well as by the thematic literature exhibited here, the distribution of "flyers" and calendars. An interesting "discovery" was the expression of the importance of the Ukrainian movement for health in the form of visual aids (models, radiographs, graphs, drawings, tables, charts, statistics, etc.), the distribution of thematic calendars, flyers. According to the researcher-historian of the UHS R. Osinchuk, these moving exhibitions were visited by almost 50,000 people; during the exhibitions about 150 "reports" were arranged [7:204].

The participation of medical students in the anti-tuberculosis and anti-alcohol campaigns of 1932 and 1933 was effective: according to our data, in 1928-1933 alone, they made about 530 "reports" on this topic in all counties of the region. An average of 60-90 people took part in each such event. This fact, as well as the arrangement together with the UHS of "anti-tuberculosis" and sanitary courses, "ambulance" courses, whose students later gave lectures in the villages, eloquently testifies to the real significant contribution of students in forming ideas about healthy lifestyles among the general population of Ukrainians [13;14].

The creation of a public education system for adults was an unprecedented educational phenomenon in the development of social medical care in Ukraine. Such "hygienic universities" in the form of training courses (of different duration and direction) were arranged by the UHS, "Ridna Shkola", "Silskyi Hospodar", "Prosvita", "Plast", "Vidrodzhennia", the Union of Ukrainian Women and other societies: for example, annually, since 1930, in December, the UHS organized three-day anti-tuberculosis courses; school doctors 
and teachers organized a "reporting campaign" in Ukrainian educational institutions; sanitary course for senior female Plast members in Lviv [7: 197-199]; sanitary and hygienic courses for members of the Anna Barvinok "Native School" Group, "Zorya", "Luh" and others to train public advocates (courses ranging from 25 to 75 participants, included a series of lectures on hygiene, common diseases and patient care, the role of women in maintaining a healthy lifestyle in a family, emergency aid for life-threatening conditions, human anatomy and physiology, etc.);we consider this form of education to be a bold innovative solution of that time, because in fact this is how educational coaching was carried out: students, having acquired relevant knowledge and professional skills of educational work, became teachers-educators themselves; having received certificates of public health advocates, they became effective participants in the health movement of Ukrainians, building a system of public medical care; by organizing three-day anti-alcohol courses for Ukrainians, the anti-alcohol and smoking section of UHS in this way diversified thematic events in February, the month of the fight against alcoholism (combined with other forms of mass education, including exhibitions, holidays, for example, in Zhovkva, Lviv, Ternopil), etc.

The special attention should be paid to the six-month courses of public hygienists. We qualify them as an important form of non-governmental women's education, which was designed to train junior staff, including assistant doctors in anti-tuberculosis counseling of the UHS, which will be discussed below. The magazine "Ukrainian Youth" actively promoted this specialty $[15 ; 16]$.In our opinion, such career guidance work in the field of public medical care gave "good results". The training of public hygienists consisted of a theoretical component (study of anatomy, human physiology, general pathology, bacteriology, basics of antiseptics and disinfection, biochemistry, endocrinology, genetics, infectious diseases, basics of hygiene, maternity and childhood care, patient care, emergency aid) and practical component, which provided practical training in a hospital ("Narodna Lichnytsia", then Metropolitan A. Sheptytskyi "Hospital "Narodna Lichnytsia"), where highly qualified doctors passed the experience to young medical staff - mostly high school students or graduates of gymnasiums and public schools, nuns, girls and young women. After successfully passing the final exam, the cadets received certificates of public hygienists and could begin their professional activities as nurses in hospitals and clinics. By 1939, there were two courses conducted, which were completed by about 100 participants.

These women and girls were actively involved in social work, became public advocates of health, effectively helped in the field of health care of Ukrainians: visited sick people at home, counseled the population, gave various professional advice to those in need of medical care, distributed free medicine, discovered new patients or suspects of tuberculosis, carried out explanatory work with them, referred to a doctor or X-ray examination, etc. [7: 212].

The personnel training for the implementation of sanitary and hygienic education was carried out by "Silskyi
Hospodar", "Ridna Shkola" and other public societies, which organized two- and three-month courses for housewives. Here much attention was paid to knowledge and skills in housekeeping, food hygiene, household hygiene, women's hygiene and more. The course program also included training in patient care; girls and women acquired knowledge (as well as developed their skills) in the field of gynecology, obstetrics, pediatrics, sanitation and hygiene. We single out the role of S. Parfanovych, O. Kysilevska (editor-in-chief of the magazine "Women's Fate" (1925-1939)), O. Duchyminska and other activists of the Ukrainian women's movement in the dissemination of knowledge in the field of hygiene and health of children and adults [17].

Considering the influence of the women's movement (in 1936, there were 145 thematic clubs for girls aged 1418 , the number of members reached about 45,$000 ; 25 \%$ of Ukrainian villages in Galicia had local centers of the Union of Ukrainian Women), when about 5\% of Ukrainian women were Union members, there are grounds to emphasize: the movement for health care covered a wide range of Ukrainian people in Galicia, particularly Ukrainian women, thus significantly contributing to the health preservation of mothers and children.

Today there is a need not only for in-depth study of the researched problem, but also for training medical workers to organize medical care for the population during a pandemic, developing new educational programs for the training of volunteer doctors, public health workers.

Sanitary and hygienic education should unite the entire conscious population. Propagandists-volunteers and participants of this movement should be not only medical workers, students of medicine, but also schoolchildren, students of colleges, universities, teachers, professors, civic activists, conscious villagers, priests. Among the main tools, methods and forms of activity that can be used in today's conditions are: "hygienic universities" for the population, especially in villages, which will focus on disseminating knowledge and promoting materials on health during the COVID-19 pandemic (in particular through the Internet and other social networks); lecture promotion of hygiene and hygienic knowledge; advising people on how to prevent the spread of COVID-19 disease; sanitary and hygienic education through the printed word (via the Internet; publications in periodicals in the form of articles or notes, separate sections); creation of the magazine "Your Health"; publication of information leaflets ("flyers", propaganda leaflets, calendars, etc.) and popular science literature in the form of thematic books; arrangement of sanitary and hygienic courses for the population; arrangement of "anti-disease" and sanitary-hygienic courses, first aid courses for volunteer doctors, in particular from among students who will later arrange such training among the population, especially in rural areas; course training of public volunteers-hygienists (of different duration and direction); introduction to the content of education in schools of the course "Fundamentals of Hygiene"; creation of thematic literary works; illustration 
of "hygienic topics" of books; mass promotion of sanitary and hygienic knowledge in mobile applications, creation of thematic videos, computer games; free counseling for people by volunteer doctors; organization of health camps, holiday centers for children, youth and adults who suffered COVID-19 in the Carpathians; creation of advice for mothers (sanitary and hygienic education of mothers) on health, prevention of diseases among children; creation of health cooperatives, where the community would hire a family doctor and a hygienist; organization of free preventive examinations of the people; providing each secondary school with a doctor; etc.

In our opinion, today these and other massive public sanitary and hygienic measures could compensate for gaps in the state health care system, focus efforts on medical care for the most vulnerable, including the rural population and children, on the formation of knowledge on the basics of hygiene and sanitation, prevention of the emergence and spread of diseases caused by the COVID-19 pandemic, the establishment of the idea of healthy nation, awareness of the importance of preserving its gene pool.

\section{CONCLUSIONS}

The driving force of sanitary and hygienic education during the studied period were medical and public figures, educators, students, conscious peasantry, activists of the women's movement, united in the Ukrainian Hygienic Society, "Narodna Lichnytsia", Ukrainian Medical Society, "Medychna Hromada" and other institutions. They focused their efforts on the fight against infectious diseases and their prevention; development of consulting activities; hygienic education and enlightenment of Ukrainians; medical care of women with children, etc.

Under the current conditions of the COVID-19 spread, analysis of this retro experience projects to develop a scientific concept of health education, which would outline theoretical approaches to studying this problem, creating a comprehensive state program aimed at preventing infectious diseases, restoration of gene elaboration of clear recommendations on observance of sanitary and hygienic norms and conditions established by quarantine zones, carrying out anti-epidemic measures at educational institutions and among the adult population, informing about prevention and peculiarities of the COVID-19 disease spread, etc. Without these measures, there are some risks of losing the gene pool of the Ukrainian nation.

\section{REFERENCES}

1. Melnychuk I., Fedchyshyn N., Pylypyshyn 0., Vykhrushch A. Philosophical and Cultural Aspects of Medical Profession: Philosophical and Conceptual Peculiarities. Cultura. International Journal of Philosophy of Culture and Axiology. 2019:16 (1): 165-174.

2. Brożek K. Ruch na rzecz podnoszenia kwalifikacji zawodowych polskich lekarzy w latach 1805-1952. Towarzystwa i kursy [Movement for the improvement of professional qualifications Polish doctors in the years 1805-1952. Societies and courses]. Medycyna Nowożytna.2003; 10(1-2): 35-98. (In Polish).
3. Hanitkevych Ya. Ukrainska medytsyna Lvova do pochatku Druhoi svitovoi viiny. NT Sh [Ukrainian medicine in Lviv before the Second World War]. 2006. http://ntsh.org/content/ukrayinska-medicina-lvovadopochatku-drugoyi-svitovoyi-viyni. (In Ukrainian).

4. tupienko A. Some remarks on the birth of modern city planning in the Polish territories. 1850- 1914: the impact of the hygienic movement. Mesto a dejiny.2016; 5: 18-34.

5. Trach V. Hihiienichni chasopysy ta formuvannia dyskursu hromadskoho zdorovia u Lvovi na pochatku XX stolittia [Hygienic periodicals and the shaping of discourse of public health in Lviv at the beginning of the twentieth century]. Misto: istoriia, kultura, suspilstvo. 2017; 2(4): 136-161. (In Ukrainian).

6. Bilavych I. Vnesok ukrainskykh likariv u rozvytok vitchyznianoi nauky ta medychnoi opiky ditei i doroslykh (kinets XIX — pochatok XX st.) [Contribution of Ukrainian doctors to development of native science and medical guardianship of children and adults (late 19th - early 20th century)]. Liudynoznavchi studii. Pedahohika. 2015; 31:25-33. (In Ukrainian).

7. Osinchuk R. Na stiitsi narodnoho zdorovia. Ukrainske Hihiienichne Tovarystvo u Lvovi [At the public health stand. Ukrainian Hygienic Society in Lviv]. Materiialy do istorii ukrainskoi medytsyny. Niu-York; Miunkhen: Ukrainske Likarske Tovarystvo Pivnichnoi Ameryky. 1975; 1: 191-224. (In Ukrainian).

8. Zvit z diialnosty Ukrainskoho hihiienichnoho t-va u Lvovi za rik 1930/31 [Report on the activities of the Ukrainian Hygienic TV in Lviv for the year 1930/31]. Lviv, 1931. 8. (In Ukrainian).

9. Zvit z diialnosty Ukrainskoho hihiienichnoho tovarystva u Lvovi za chas vid $21.01 .1929 \mathrm{do} 28.11 .1930 \mathrm{rr}$. [Report on the activities of the Ukrainian Hygienic Society in Lviv for the period from January 21, 1929 to November 28, 1930]. Lviv, 1930. 12. (In Ukrainian).

10. Vorobets T. Na storozhi narodnoho zdorovia (Filiia Ukr. Hihiienichnoho T-va v Terebovli) [Onguard of public health (Branch of Ukrainian Hygienic TV in Terebovlia)]. Terebovlianska zemlia. Istorychno-memuarnyi zbirnyk. Niu-York; Paryzh; Sidnei; Toronto: NTSh. Ukrainskyi arkhiv, 1968. pp. 317-321. (In Ukrainian).

11. Vystavka u Khodorovi [Exhibition in Khodorov]. Narodnie zdorovlia. 1937; 1: 4. (In Ukrainian).

12. Vidkryttia hihiienichnoi vystavky v Kopychyntsiakh [0pening of a hygienic exhibition in Kopychyntsi]. Narodnie zdorovlia. 1938; 1: 13. (In Ukrainian).

13. Vid Ukrainskoho Hihiienichnoho Tovarystva [From the Ukrainian Hygienic Society]. Dilo. 1929; 4 hrudnia: 5-6. (In Ukrainian).

14. 25-littia"Narodnoi Lichnytsi" [25th anniversary of the "Narodnoi Lichnytsi"]. Lviv. 1930. 14. (In Ukrainian).

15. lak pratsiuiut nashi divchata. Pomichnytsia u likarky [How our girls work. Assistant to doctors]. Svit molodi. 1936; 4 (1):7-8. (In Ukrainian).

16. lak pratsiuiut nashi divchata. Dohliadachka khorykh (zakinchennia) [How our girls work. Chorus nurse (end)]. Svit molodi. 1937; 3: 10-11. (In Ukrainian).

17. Stytsiuk N., Zolotarova Zh., Stovban I., Yukish H. Women's modernism in medical science of Western Ukraine - Sofia Okunevska-Morachevska, Sofia Parfanovych and Volodymyra Krushelnytska. Wiadomości Lekarskie. 2021; 74(3p.II): 784-787. doi: 10.36740/WLek202103241

The work was carried out according to the research work of Ternopil National Medical University for 2019-2021 on the theme of "Professional training of future specialists in the medical field on the basis of interdisciplinary integration" (state registration number 0116U004031). 


\section{ORCID and contributionship:}

Halyna V. Bilavych: 0000-0002-1555-0932 A,D,F

Jan V. Bilawicz: 0000-0003-4561-4690 E,D

Larysa V. Slyvka: 0000-0003-1865-6326 E,F

Mariia V. Klepar: 0000-0003-4923-8696 ${ }^{B, D}$

Mykola P. Pantiuk: 0000-0001-7336-6714 ${ }^{B, D}$

Nadiya O. Fedchyshyn: 0000-0002-0909-4424 ${ }^{B, F}$

Borys P. Savchuk: 0000-0003-2256-0845 C,E

\section{Conflict of interest:}

The Authors declare no conflict of interest

\section{CORRESPONDING AUTHOR}

\section{Nadiya 0. Fedchyshyn}

Ternopil National Medical University

Maidan Voli, 1, 46001, Ternopil, Ukraine

tel: +380977008085

e-mail: fedushunno@tdmu.edu.ua

Received: 16.05 .2021

Accepted: 25.08 .2021

A - Work concept and design, B - Data collection and analysis, C - Responsibility for statistical analysis,

D-Writing the article, $\mathbf{E}-$ Critical review, $\mathbf{F}$ - Final approval of the article 